\title{
THE PLANT-LEVEL VIEW OF AN INDUSTRIAL POLICY: THE KOREAN HEAVY INDUSTRY DRIVE OF 1973
}

\author{
Minho Kim \\ Munseob Lee \\ Yongseok Shin \\ Working Paper 29252 \\ http://www.nber.org/papers/w29252 \\ NATIONAL BUREAU OF ECONOMIC RESEARCH \\ 1050 Massachusetts Avenue \\ Cambridge, MA 02138 \\ September 2021
}

This paper uses confidential data from Statistics Korea. The data agreement involves a request for review of the findings prior to their release. The views expressed in this paper, however, are the authors' own and not necessarily those of Statistics Korea. The views expressed herein are those of the authors and do not necessarily reflect the views of the National Bureau of Economic Research.

NBER working papers are circulated for discussion and comment purposes. They have not been peer-reviewed or been subject to the review by the NBER Board of Directors that accompanies official NBER publications.

(C) 2021 by Minho Kim, Munseob Lee, and Yongseok Shin. All rights reserved. Short sections of text, not to exceed two paragraphs, may be quoted without explicit permission provided that full credit, including $\left({ }^{\circ}\right.$ notice, is given to the source. 
The Plant-Level View of an Industrial Policy: The Korean Heavy Industry Drive of 1973

Minho Kim, Munseob Lee, and Yongseok Shin

NBER Working Paper No. 29252

September 2021

JEL No. E24,O14,O25,O53

\begin{abstract}
$\underline{\text { ABSTRACT }}$
Does industrial policy work? This is a subject of long-standing debates among economists and policymakers. Using newly digitized microdata, we evaluate the Korean government's policy that promoted heavy and chemical industries between 1973 and 1979 by cutting taxes and building new industrial complexes for them. We show that output, input use, and labor productivity of the targeted industries and regions grew significantly faster than those of non-targeted ones. While the plant-level total factor productivity also grew faster in targeted industries and regions, the misallocation of resources within them got significantly worse, especially among the entrants, so that the total factor productivity at the industry-region level did not increase relative to the nontargeted industries and regions. In addition, we provide new evidence on how industrial policy reshapes the economy: (i) The establishment size distribution of targeted industries and regions shifted to the right with thicker tails due to the entry of large establishments and (ii) the targeted industries became more important in the economy's input-output structure in the sense that their output multipliers increased significantly more.
\end{abstract}

Minho Kim

Korea Development Institute

263, Namsejong-ro

Sejong-si 30149

Korea

minhokim@kdi.re.kr

Munseob Lee

University of California at San Diego

9500 Gilman Drive, \#0519

La Jolla, CA 92093-0519

munseoblee@ucsd.edu
Yongseok Shin

Department of Economics

Washington University in St. Louis

One Brookings Drive

St. Louis, MO 63130

and NBER

yshin@wustl.edu 


\section{Introduction}

During the East Asian growth miracle periods, governments were heavily involved in the economy and selectively nurtured specific industries and companies. However, there is no definitive answer as to the effectiveness of industrial interventions (Noland and Pack, 2003; Harrison and Rodríguez-Clare, 2010). Using newly-digitized microdata, we re-visit Korea's industrial policy during the 1970s. Relative to previous research that relied on industrylevel data, e.g. Lee (1996) and Lane (2021), we make progress in two ways. First, we utilize the fact that the policy targeted not only specific industries but also specific regions. This

place-based nature of the policy is crucial for understanding the effectiveness of industrial policy. Second, we provide the first analysis of the pattern of resource allocation across manufacturing plants during this policy period.

The policy in question is the 1973-1979 heavy and chemical industry drive of the Park regime. The government launched the drive in 1973 for at least two reasons. First, North Korea's military provocations and the partial pullout of the US troops from South Korea in 1971 motivated the government to strengthen its military capabilities by promoting defense industries and their upstream industries (Ahn and Kim, 1995; Lane, 2021). The other motivation was to further promote export, with the explicit target annual export of 10 billion US dollars. The government had been influenced by Japan's experience in this regard. By switching from the traditional labor-intensive, light industries to heavy and chemical industries in 1957, Japan's annual export exceeded 10 billion dollars by 1967 . Government support for the targeted industries in Korea came in various forms, such as tax incentives, subsidized long-term loans, and constructing industrial complexes for them. The policy did not last. After the assassination of President Park in 1979, the next administration adopted private sector-led growth as the core of their new economic policy, following a period of "rationalization" that was meant to undo the excess investment in the heavy and chemical industries (SaKong and Koh, 2010).

Because the heavy industry drive represents an abrupt change in the government's policy direction in 1973, we utilize a difference-in-differences specification to evaluate the impact of the policy on the targeted industries/regions relative to non-targeted ones.

Our main findings are as follows. First, under the policy, the output, input use, and labor productivity of the targeted industry-region pairs grew significantly faster than those of the non-targeted ones, while the number of plants did not show differential growth. The differential outcomes between the targeted and the non-targeted industry-region pairs did not follow a divergent pre-trends, supporting a causal interpretation. Second, while the plant-level total factor productivity rose significantly for the plants in the targeted industries and regions, the 
total factor productivity at the industry-region level did not change relative to that of the non-targeted ones. The reason is that the allocative efficiency worsened significantly within the targeted industries and regions, with production activities growing more concentrated but not necessarily toward the plants with the highest productivity. The misallocation was especially severe among the plants in the targeted industries/regions that entered during the policy period. This evidence is consistent with the rise of large business groups (known as chaebols) and the cross-subsidization practices of their business units during this period (SaKong and Koh, 2010). A simple accounting exercise following Hsieh and Klenow (2009) shows that, if the degree of misallocation within the targeted industries/regions relative to the degree within the non-targeted ones had remained the same between 1968 and 1980, their average total factor productivity would have been 40 percent higher in 1980 .

In addition, we provide new evidence on the ways in which industrial policy reshapes the economy. First, the establishment size distribution of the targeted industries and regions shifted to the right (i.e., larger establishments), with the right tail becoming noticeably thicker. The shift is mostly accounted for by the entry of large plants in the targeted industries/regions during the policy period. This is consistent with what happens in models of technology adoption, where the thicker right tail is a result of more firms adopting advanced technology (Buera, Hopenhayn, Shin and Trachter, 2021), although in our data the relationship between plants' productivity and size became more misaligned during the policy period. Second, during the policy period, the input-output structure of the economy evolved in a way that the targeted industries significantly increased their output multipliers. To the best of our knowledge, this is the first evidence in the literature drawing attention to the evolution of an economy's input-output structure. ${ }^{1}$ This evolving input-output structure implies that the expansion of the targeted industries may have helped the non-targeted ones by supplying cheaper intermediate inputs. In this vein, the differential impact of the policy we identify may significantly underestimate the overall impact of the policy on the economy.

The impact of the policy outlasted the policy itself. The impact on output, input, labor productivity, establishment size, and input-output structure remained nearly intact at least until 1990. One exception is the degree of misallocation within the targeted industries/regions. It fell significantly with the reversal of the policy after 1979, but nevertheless remained above its pre-policy level.

Then, was the Korean heavy industry drive a success? One conclusion we can safely draw without a full cost-benefit analysis is that the policy would have had a more positive effect if the promotion of the targeted industries and regions had not come with a rise in

\footnotetext{
${ }^{1}$ Liu (2019) and Lane (2021) used the input-output structure in 1970 to consider the effectiveness of Korea's industrial policy. We compare the input-ouput structure in 1970 with that in 1980.
} 
concentration and misallocation within them.

Related Literature. This paper contributes to a long-standing debate on industrial policy. Until recently, econometric evaluations were rare - see the review of Lane (2020). Using quasi-experimental designs, Giorcelli (2019), Hanlon (2020), and Juhász (2018) evaluated the effectiveness of historical policies. Aghion, Cai, Dewatripont, Du, Harrison and Legros (2015), Criscuolo, Martin, Overman and Van Reenen (2019), Manelici and Pantea (2021), and Rotemberg (2019) quantify the impact of contemporary interventions with rich microdata from various countries. We use recently-digitized microdata to study the changes within and between plants during and after the policy through exploiting its industrial and regional variation. The reallocation within industry and region is an important margin for aggregate productivity.

Also related is the literature exploring the impact of policy changes on resource allocation within a country, in particular the liberalization of capital flows. Gopinath, Kalemli-Özcan, Karabarbounis and Villegas-Sanchez (2017) found that increased access to foreign debt worsened resource allocation across firms in Spain, whereas Bau and Matray (2020) found that capital account liberalization reduced misallocation in India.

Finally, our analysis helps settle the renewed debate on the Korean industrial policy, which had often been hailed as a success story (for example, Kim and Leipziger, 1997). Analyzing industry-level variables, Lane (2021) concluded that the heavy industry drive of 1973 raised output and labor productivity of the targeted industries and its downstream industries. This contrasts with Lee (1996), who documented a negative relationship between policy interventions and industry-level outcomes. We find that the heavy industry drive of 1973 did increase output but did not increase the total factor productivity of targeted industries, because resource misallocation within the targeted industries worsened. ${ }^{2}$

\section{Background}

During the rapid industrialization and globalization of the Korean economy, the direction of the government policy has changed abruptly multiple times. A systematic effort to jumpstart the economy was inaugurated in 1962 in the form of the first Five-Year Plan. Initially, the government focused on infrastructure and on labor-intensive industries such as garments and textiles. The heavy industry drive of 1973, partly motivated by the Nixon doctrine and

\footnotetext{
${ }^{2}$ Choi and Levchenko (2021) use firm-level data from historical annual reports starting from 1970 and find that the effect of industrial policy at the firm level persisted through the 2010s. This is consistent with the persistent effect on output and input use at the industry/region-level that we find through the end of our sample period, 1987, and also with the persistent industry-level effect in Lane (2021).
} 
North Korea's military provocations (Woo, 1991) and partly by Japan's successful export promotion in the previous decade, was a monumental shift. President Park Chung-hee stated in January 1973 that "the government is announcing the Heavy and Chemical Industry (HCI) project. To achieve a 10 billion dollar target of annual exports by the early 1980s, the share of HCIs in total exports should be raised to well over 50 percent. From now on, the government will accelerate the promotion of HCIs such as steel, shipbuilding and petrochemical industries, and thereby increase their exports" (Park, 2005).

Figure 1 shows the two main instruments of the heavy industry drive. Panel (a) shows the effective tax rates across nine industries from Kwack (1985), who constructed them from the relevant legislation promoting investment in targeted industries. In particular, he computed the effective corporate tax rates using the investment deduction, depreciation schedule (including accelerated depreciation), tax holiday, and reserve allowance (a form of deferred tax payment) by industry and by capital type in the tax law. During the policy period, there was a stark divergence in effective tax rates between targeted and non-targeted industries. Targeted industries in panel (a) were "Chemical," "Primary Metal," and "Fabricated Metal Products, Machinery and Equipment."

Panel (b) shows the locations of industrial complexes during the policy period. In February 1974, the government established the Korean Industrial Complex Corporation, charged with the construction of industrial sites and the necessary infrastructure for targeted industries. The government invested 100 billion won (247 million US dollars in 1974) in the Corporation, which had special privileges, including tax exemption, the right to appropriate land, and the right to borrow money from overseas (SaKong and Koh, 2010). Six locations (Changwon, Yeocheon, Onsan, Okpo, Anjeong, Jukdo) were initially chosen in early 1974. Two other places (Ulsan, Pohang) were added in late 1974 and another (Gumi) was added in 1977 . These areas had previously been remote rural areas but grew rapidly between the mid-1970s and the mid-1980s due to the policy drive.

The heavy industry drive of 1973 ended unexpectedly after President Park was assassinated in October 1979. In the early 1980s, the new regime drastically changed the policy direction. President Chun Doo-hwan adopted "stability" and "private sector-led growth" as its slogan (SaKong and Koh, 2010). These changes were overseen by economists and technocrats who studied in the United States (Woo, 1991), and were embodied in the fifth Five-Year Plan (1982-1986). Panel (a) of Figure 1 shows that the gap in effective tax rates between targeted and non-targeted industries disappeared by 1982 . The main goal of regional development also shifted from promoting heavy industries in the 1970s to curbing concentration in the Seoul metropolitan area in the 1980s. 


\section{Figure 1: Policies Targeting Industries and Regions}

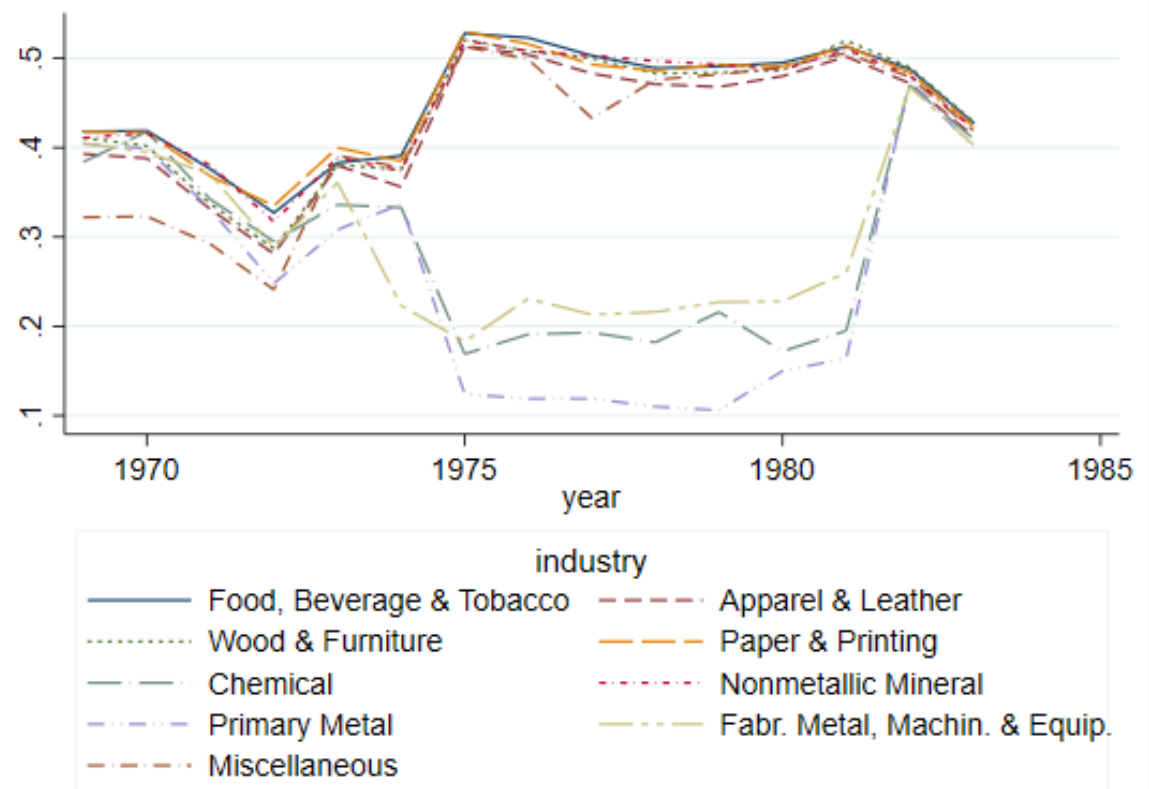

(a) Effective Tax Rates

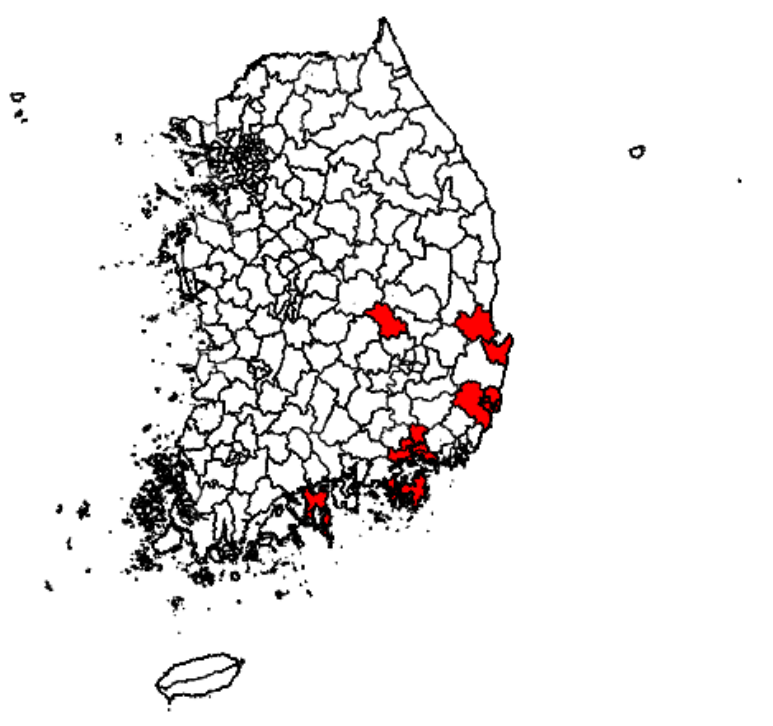

(b) Construction of Industrial Complexes in Korea

Notes: Panel (a) is the effective tax rates for nine broad industry categories from 1969 to 1983 . These numbers are calculated and reported by Kwack (1985). Panel (b) shows the location of the nine industrial complexes planned and built during the policy period. 


\section{Data}

We use Statistics Korea's annual Mining and Manufacturing Survey (MMS) from 1967 to 1987, except for the two missing years of 1970 and 1972. ${ }^{3}$ The MMS covers all establishments with at least five employees in the mining and manufacturing sector. Plant-level data includes gross output, fixed assets, number of employees, wages paid in total, costs of intermediate inputs and location at the province level. Prior to 1978, the fixed asset data is available in only one year, $1968 .^{4}$

We convert nominal gross output and intermediate input values to real measures using industry-level producer price indices obtained from the Economic Statistics System (ECOS) of the Bank of Korea. We then harmonized them to match industries between the Bank of Korea classification and the Korean Standard Industry Classification (KSIC). Real value added is defined as real gross output minus real intermediate input. Capital stock is the sum of the total fixed asset values of building structures, machinery, and transport equipment. The deflator for each type of capital stock is calculated using nominal and real values of the gross capital formation in national accounts in the ECOS.

The MMS's industrial classification is at the four-digit (before 1970) or five-digit level (since 1970) of the KSIC. During the period in our analysis, the KSIC was revised four times (Revision 2 in 1968, 3 in 1970, 4 in 1975, and 5 in 1984). We constructed a harmonized three-digit industry classification using a crosswalk based on the concordance tables for each revision. We excluded establishments belonging to the mining and the tobacco industries.

In June 1973, the heavy industry drive committee selected six strategic industries: steel, non-ferrous metal, petrochemical, machinery, shipbuilding, and electronics. After we reviewed historical documents on the Five-Year Plans, we were able to determine which 3- or 4-digit industries were targeted. One important caveat is that the heavy industry drive of 1973 was not the first industrial policy in Korea (Stern, Kim, Perkins and Yoo, 1995). In fact, it was part of the second Five-Year Plan. Several of the targeted industries had been targeted before 1973, but they did not receive meaningful support due to the lack of technological expertise and financial resources. The exceptions were chemical, refined petroleum, and cement industries, which by 1973 had already some track record of growth aided by the

\footnotetext{
${ }^{3}$ The Mining and Manufacturing Survey (MMS) started in 1967. Even though there were other surveys covering mining and manufacturing establishments before 1967, plant-level microdata is only available from the MMS. We include eight more years in the sample after the demise of the Park regime in 1979, to see whether the policy had longer-lasting effects. A democratic uprising in 1987 and the Roh Tae-Woo administration's guiding principle of "economic democratization" drastically changed the structure of the Korean economy and the economic policy, so we do not include the post-1987 period in the study.

${ }^{4}$ The annual report on MMS published by the Economic Planning Board of Korea reports industry-level aggregates based on this microdata. Lane (2021) used this industry-level data at the five-digit level from 1970 to 1986.
} 
government, often in the form of joint ventures involving foreign companies. Appendix Table A.I shows the list of industries. We marked an industry as "treated" if the industry was the target of the heavy industry drive of 1973. We also separately mark the three industries that had been materially supported by the government before 1973 .

One important feature of the heavy industry drive of 1973 when compared with earlier policies was that the government developed industrial complexes specializing in each of the six strategic industries. These industrial complexes were located in three eastern and southern provinces. As a result, geographic regions provide another dimension of variation that helps assess the impact of the heavy industry drive. We show which regions were targeted at the province level in Appendix Table A.II.

We also use the input-output (IO) matrix in 1970 and 1980 to compare industry linkages before and after the heavy industry drive of 1973-1979. The original IO matrices from the Bank of Korea have 64 manufacturing industries in 1970 and 72 in 1980, which we harmonized into 54 industries.

\section{Empirical Findings}

\subsection{Output, Input, and Productivity}

We first explore the effect of the industrial policy on output, input, and productivity of targeted industry-region pairs. Out of 28 harmonized three-digit industries, 12 industries were targeted by the heavy industry drive. For our analysis, we drop the establishments in three of the 12 targeted industries (chemicals, refined petroleum, and cement), which had been materially supported by the government before 1973 (Appendix Table A.I) to isolate the effect of the drive. As for the target region, 3 out of 11 provinces hosted industrial complexes for the targeted industries (Appendix Table A.II). We focus on the industry-region pairs with a targeted industry in a targeted region, and compare them with the industry-region pairs with a non-targeted industry in a non-targeted region.

We use a difference-in-difference estimator to estimate the impact of the policy:

$$
\log Y_{i c t}=\alpha+\sum_{j=\{1967-1969\} \cup\{1973-1987\}} \beta_{j}\left[D_{i c} \times \mathrm{Year}_{t}^{j}\right]+\gamma_{i}+\delta_{c}+\theta_{t}+\epsilon_{i c t}
$$

where $Y_{i c t}$ is an outcome variable for an industry $i$ in a region $c$ in year $t . D_{i c}$ is a binary indicator equal to one if the industry and the region were treated and zero otherwise. The variables $\gamma_{i}, \delta_{c}$, and $\theta_{t}$ are industry, region, and year fixed effects, respectively. Plant-level data does not exist for 1970 and 1972. By dropping 1971 from the regression, $\beta_{j}$ 's show the 
differential evolution of targeted and non-targeted industries and regions relative to 1971 . We adjust standard errors with two-way clustering over industries and regions. The regressions are weighted by the average of outcome variables over the sample period $\left(\sum_{t=1967}^{1987} Y_{i c t}\right)$ for output and input variables. The labor productivity regression is weighted by employment and the total productivity regression by value-added.

Panels (a)-(f) of Figure 2 plot the estimated $\beta_{j}$ 's in our difference-in-differences equation from 1967 to 1987 for six outcome variables. ${ }^{5}$ Panel (a), (b), and (d) show that the targeted industry-region pairs and the non-targeted ones evolved similarly between 1967 and 1971. This parallel pre-trends support a causal interpretation: Without the industrial policy, the targeted industry-region pairs and the non-targeted ones would have evolved similarly.

Panel (a) shows the evolution of the real value-added of the targeted industry-region pairs relative to that of the non-targeted industry-region pairs. The real value-added of the targeted industry-region pairs increased significantly more during the policy period, and the difference remained through the 1980s even after the policy ended. We find similar patterns in the number of employees in Panel (b). Panel (c) shows real capital stock. The microdata for capital only exists for 1968 and for 1978 and after. Therefore, we make 1968 the baseline year for all capital related variables. Real capital stock significantly increased during the policy period. From panels (a)-(c), we see that the targeted industries in the targeted regions used significantly more inputs and produced significantly more output during and after the heavy industry drive relative to the non-targeted industries in non-targeted regions. Although not shown here, these differential increases in industry/region-level output and input did not come from a differential increase in the number of establishments. We find no significant differences in the growth of the number of establishments between the targeted and the non-targeted industry-region pairs.

Since both output and input grew significantly more for the targeted industries/regions, it is natural to ask what happened to productivity. Panel (d) shows the labor productivity, which grew much faster in the targeted industry-region pairs than the non-targeted ones, consistent with a comparison of the magnitude in panels (a) and (b). We see that the differential growth in capital is much larger than that in value-added or labor input, which would explain this labor productivity result. In panel (e), we show the total factor productivity. Because the capital data is missing between 1969 and 1977, we again make 1968 the baseline year. We calculate the total factor productivity of industry-region pairs by averaging plant-level total factor productivity with value-added as weights. ${ }^{6}$ The total factor produc-

\footnotetext{
${ }^{5}$ Appendix Figure B.1 shows the levels (rather than the differences) of these outcome variables for the targeted and non-targeted industry-region pairs over time.

${ }^{6}$ Appendix D explains our calculation of plant-level total factor productivity.
} 


\section{Figure 2: Output, Input, and Productivity}

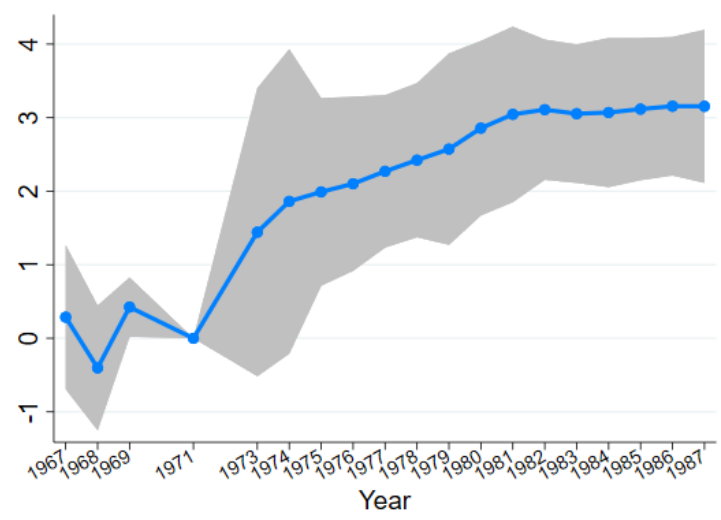

(a) Real Value-added

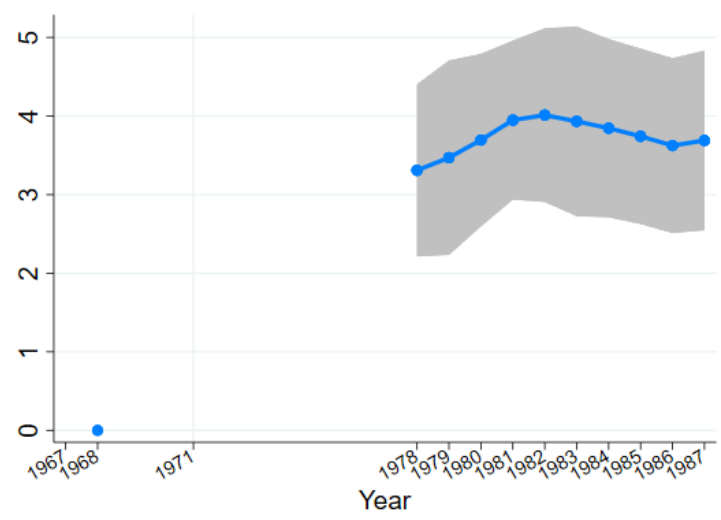

(c) Real Capital Stock

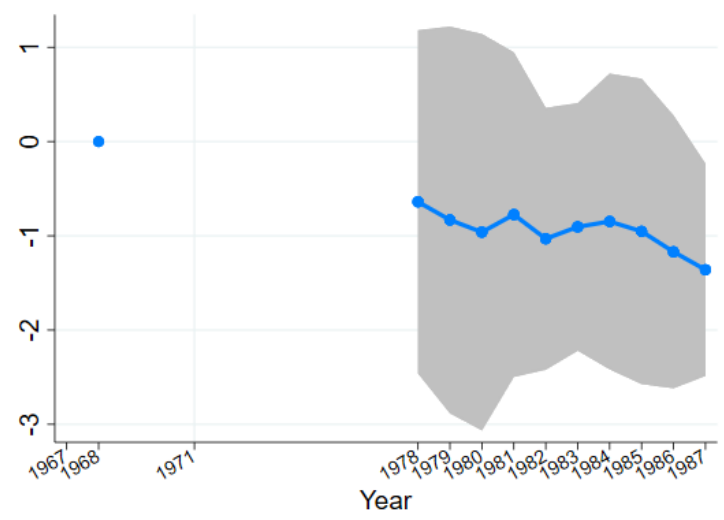

(e) Total Factor Productivity

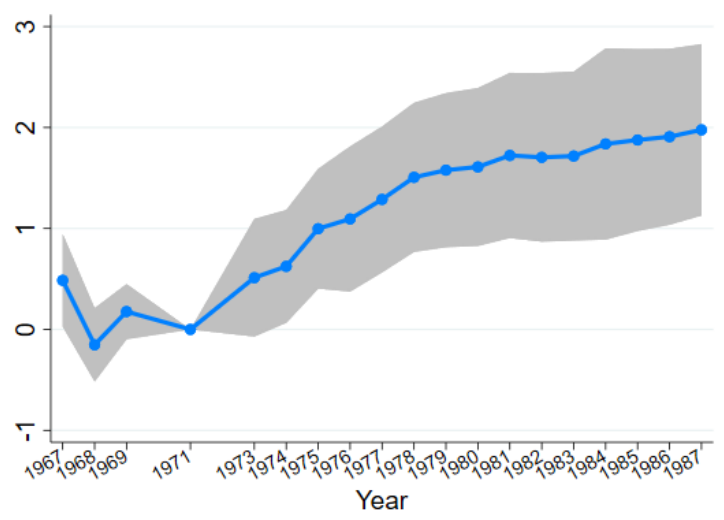

(b) Number of Employees

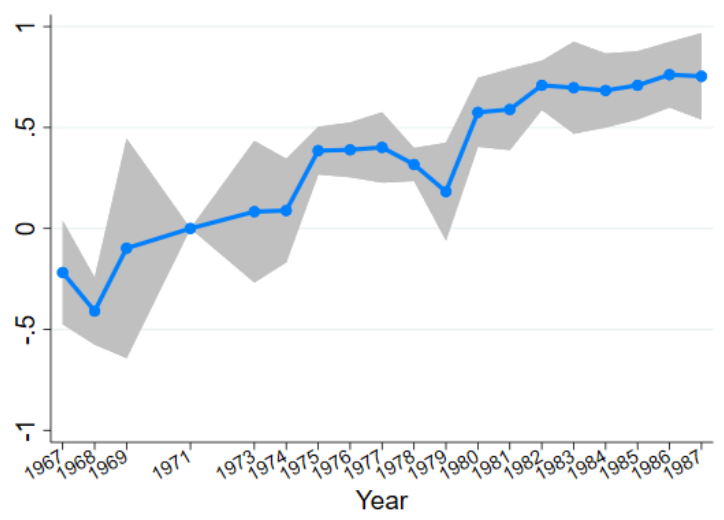

(d) Labor Productivity

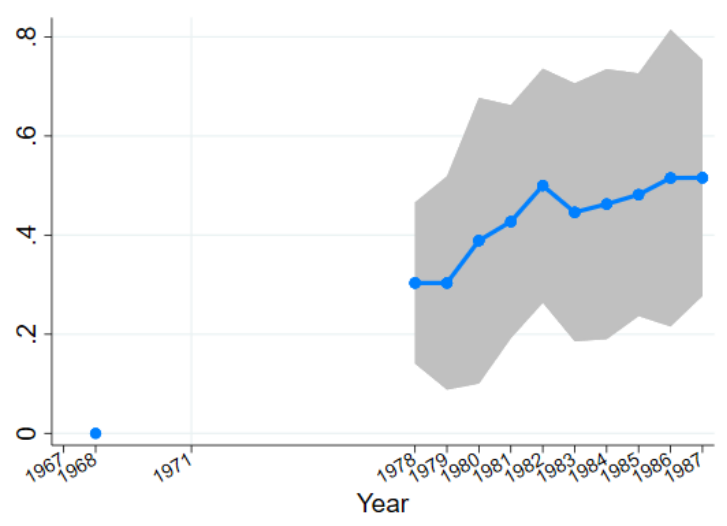

(f) Simple Average of Establishment-level TFPs

Notes: Panels (a) to (f) plot the estimated coefficients along with a 95 percent confidence interval from equation 1. The microdata does not exist in 1970 and 1972, and the year of 1971 is normalized to zero. We adjust standard errors with two-way clustering over industry and region. Regression weights are the average size of outcome variable over the sample period in panels (a), (b), and (c). We use number of employees as a regression weight for panel (d) and real value added for panel (e) and (f). 
tivity does not show differential growth. We conclude that the heavy industry drive of 1973 allocated significantly more factors of production into the targeted industry-region pairs but did not increase the total factor productivity at the industry/region level. ${ }^{7}$

However, there is more to this non-result on total factor productivity. Panel (f) shows the unweighted average of establishment-level total factor productivity. Unlike in panel (e), the unweighted average in the targeted industry-region pairs increased significantly more than in the non-targeted ones. In other words, the plant-level total factor productivity increased significantly more in the targeted industries/regions during and after the policy, but resource allocation across plants within the targeted industries/regions worsened substantially, to the point where the gains in plant-level productivity are completely undone by the worsened misallocation. We investigate the allocation of resources within an industry-region pair in the next section.

Before we move on, we note that it is important to consider government interventions to industries and regions jointly. Appendix $\mathrm{C}$ shows the estimated $\beta_{j}$ 's when we consider only industry targets. Point estimates are moving in the same direction overall, but their magnitudes are much smaller and much of the statistical significance is lost.

\subsection{Allocative Efficiency}

The total factor productivity at the industry/region level depends not only on the average productivity of establishments but also on the allocative efficiency across them. Following up on the result of stagnant aggregate productivity and higher plant-level productivity growth in the targeted industry-region pairs relative to the non-targeted ones, we now analyze the changes in allocative efficiency within industries/regions during and after the Korean heavy industry drive.

We first consider the concentration of output and input in the top decile of plants. The fraction of value-added accounted for by the top decile of plants in the targeted industries/regions was 65 percent in 1968 but increased significantly to 93 percent in 1978. The corresponding number in the non-targeted industries/regions remained around 82 percent over the same period. ${ }^{8}$ For the targeted industries/regions, the concentration of employment and capital inputs in the top decile also rose rapidly from 53 and 65 percent in 1968 to 81 and 95 percent in 1978, respectively. In contrast, the numbers stayed constant at 70 percent and 83 percent in the non-targeted industries/regions over this period. This implies that the significant growth in value-added, employees and capital inputs of the targeted indus-

\footnotetext{
${ }^{7}$ This last result is consistent with Lee (1996), who found no correlation between tax incentives and industry-level total factor productivity growth across sectors in Korea.

${ }^{8}$ The concentration measures for sales showed a very similar trend.
} 
tries/regions shown in Figure 2 (a) to (c) was not evenly distributed across plants in the targeted industries/regions.

The rising concentration in the targeted industries/regions does not necessarily imply worsening misallocation. We can measure the degree of resource misallocation by the dispersion of revenue productivity. Foster, Haltiwanger and Syverson (2008) made a distinction between physical productivity (TFPQ) and revenue productivity (TFPR), and Hsieh and Klenow (2009) showed that-under simple parametric assumptions on preferences and production technology - TFPR dispersion represents establishment-specific distortions and hence resource misallocation. We apply the methodology of Hsieh and Klenow (2009) at the level of industry-region pairs and express the TFP at the industry-region level (indexed by $s)$ as follows.

$$
\operatorname{TFP}_{s}=\left(\sum_{i=1}^{N_{s}}\left(A_{s i} \frac{\overline{T F P R}_{s}}{T F P R_{s i}}\right)^{\sigma-1}\right)^{\frac{1}{\sigma-1}}
$$

where $A_{s i}$ is establishment $i$ 's TFPQ defined as $Y_{s i} / K_{s i}^{\alpha_{s}}\left(w L_{s i}\right)^{1-\alpha_{s}}, T F P R_{s i}=P_{s i} A_{s i}$ is the TFPR defined as the TFPQ multiplied by its output price, and $\overline{T F P R}$ is the geometric average of the marginal revenue products of capital and labor. Assuming that TFPQ and TFPR follow a joint log-normal distribution, equation (2) gives

$$
\log T F P_{s}=\frac{1}{\sigma-1} \log \left(\sum_{i=1}^{N_{s}} A_{s i}^{\sigma-1}\right)-\frac{\sigma}{2} \operatorname{var}\left(\log T F P R_{s i}\right)
$$

Clearly, the variance of log TFPR adversely affects the aggregate TFP. We use the parameter values of Kim, Oh and Shin (2017), who measured the allocative efficiency of the Korean manufacturing sector for the 1982-2007 period. $^{9}$

Panel (a) of Figure 3 shows the evolution of the standard deviation of TFPR in the targeted industry-region pairs relative to that in the non-targeted ones. ${ }^{10}$ Although we do not know what happened during the intervening years due to the lack of micro-level capital data between 1969 and 1977, the standard deviation of TFPR in the targeted industry-region pairs increased significantly more than in the non-targeted ones between 1968 and 1978, although it fell somewhat after 1979. We conclude that the allocative efficiency worsened in

\footnotetext{
${ }^{9}$ The capital rental rate is set to 0.1 and the elasticity of substitution between plant value-added to 3 following Hsieh and Klenow (2009). We assume the elasticity of output to capital for each industry to be 1 minus its labor share in 2005. The labor share is defined as the share of wages paid to value added for each industry. The mean and the standard deviation of the labor shares across the 28 industries are 0.44 and 0.20. Since the labor shares here are much lower than the labor share in the national input-output table, we scaled up the labor shares by a constant factor, 1.89 .

${ }^{10} \mathrm{We}$ note that these are difference-in-differences estimates net of industry, region and time fixed effects as shown in equation (1). In addition, measurement errors are not a concern unless they vary over time systematically between the targeted and the non-targeted groups.
} 


\section{Figure 3: Allocative Efficiency}

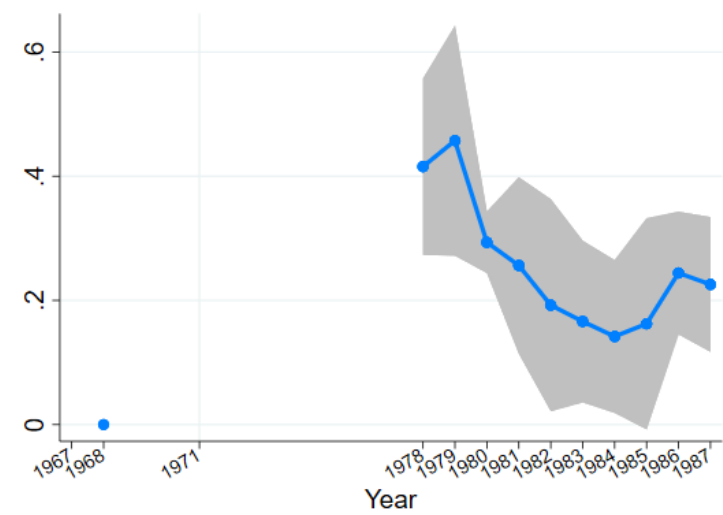

(a) Standard Deviation of TFPR

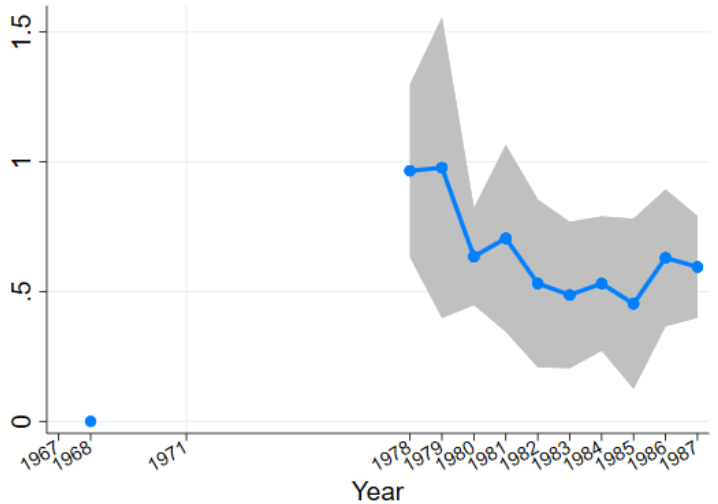

(b) Correlation b/w TFPR \& TFPQ

Notes: Panels (a) to (b) plot estimated coefficients along with a 95 percent confidence interval from equation 1. We adjust standard errors with two-way clustering over industry and region. Regression weights are real value added.

the targeted industries/regions relative to the non-targeted ones during the industrial policy period.

In addition, panel (b) shows that, in the targeted industries/regions, those plants with high TFP were subject to higher idiosyncratic distortions (positive correlation between TFPQ and TFPR) relative to the high TFP plants in the non-targeted ones. This pattern got stronger during the policy period. This evidence of worsening misallocation within industries/regions is consistent with the observation in Figure 2 that the weighted average of TFP in the targeted industries/regions did not increase while the plant-level TFP increased.

Overall, the results here provide micro-level evidence that the heavy industry drive may have come at the cost of worsening resource misallocation within the targeted industries/regions, undoing any positive effect it had on plant-level productivity. The lack of data on the ownership of these plants does not allow us to investigate resource allocation across business groups (chaebols). Anecdotally, the chaebols took advantage of the new opportunities presented by the heavy industry drive of 1973 by founding new business units in the targeted industries and directing other units within the same business group to fund and subsidize the new ventures. In addition, the government gave some of the leading chaebols preferential treatments (SaKong and Koh, 2010). ${ }^{11}$ Our view is that such direct and indirect discriminatory support contributed to the worsening resource misallocation across plants

\footnotetext{
${ }^{11}$ For example, President Park favored Chung Ju Yung of the Hyundai Group with contracts for bridges, dams and roads, and Hyundai Construction funded Hyundai Motors until the latter became competitive. Since the late 1980s, Korea introduced more transparent procurement system (Lee, 2021).
} 
within growing industries and regions.

The improving allocative efficiency after 1979 in Figure 3 is consistent with the reversal of the heavy industry drive following the assassination of President Park in 1979. The successors implemented a policy of rationalizing or undoing the over-investment in heavy and chemical industries, often by forcing mergers and acquisitions (SaKong and Koh, 2010).

The Economic Impact of the Worsened Misallocation Equation (3) allows us to quantify, albeit approximately, the economic impact of the worsened allocative efficiency in the targeted industries/regions. From 1968 to 1980, the variance of log TFPR increased by 34 percent on average across the targeted industries/regions, but actually declined by 24 percent on average across the non-targeted industries/regions. We calculate what the TFP of the targeted industries/regions would have been if the degree of misallocation within them relative to the degree within the non-targeted ones had remained the same between 1968 and 1980. Under this counterfactual scenario, the average total factor productivity of the targeted industries/regions would have been higher than their actual average by $0.34 \log$ point, or about 40 percent, in 1980. In other words, the exacerbated misallocation within the targeted industries/regions relative to the non-targeted ones had the effect amounting to a 2.8-percent-per-year loss in total factor productivity during this period.

Misallocation among Entrants vs. Incumbents In the MMS, the establishment age variable is only available from 1980, and we cannot distinguish between entrants and incumbents during the policy period (1973-79). However, in the 1980 data, we can see whether the plants that entered during the policy period (age 0-7, 'young plants') and the plants that had existed prior to the policy (age 8 and older, 'old plants') contributed to the misallocation in a different manner. One obvious limitation is that this backward-looking analysis misses the plants that exited before 1980 .

For each industry and region, we can decompose the variance of TFPR as follows to quantify the relative contribution of the young and old plants (noted by $y$ and $o$, respectively):

$$
\begin{aligned}
\operatorname{Var}\left(\mathrm{TFPR}_{i}\right) & =\frac{N_{y}}{N_{y}+N_{o}} \operatorname{Var}_{y}\left(\mathrm{TFPR}_{i}\right)+\frac{N_{o}}{N_{y}+N_{o}} \operatorname{Var}_{o}\left(\mathrm{TFPR}_{i}\right) \\
& +\frac{N_{y}}{N_{y}+N_{o}}\left(\overline{\mathrm{TFPR}}_{y}-\overline{\mathrm{TFPR}}\right)^{2}+\frac{N_{o}}{N_{y}+N_{o}}\left(\overline{\mathrm{TFPR}}_{o}-\overline{\mathrm{TFPR}}\right)^{2}
\end{aligned}
$$

where $N_{y}$ and $N_{o}$ are the number of the young and old plants, and $\overline{\mathrm{TFPR}}_{y}$ and $\overline{\mathrm{TFPR}}_{o}$ are the respective group mean of TFPR. The first term on the right-hand side is the TFPR variance among the young plants. It accounts for 74 percent of the total TFPR variance in 
the targeted industries/regions on average, and 65 percent in the non-targeted ones. The second term is the TFPR variance among the old plants, which accounts for 24 percent of the total variance in the targeted industries/regions and 33 percent in the non-targeted ones. The third and fourth terms capture the difference between the group mean and the overall mean, but are quantitatively negligible. The variance decomposition shows that the plants that entered during the policy period may have been responsible for the worsened resource misallocation in the targeted industries/regions.

\subsection{Establishment Size Distribution}

The results in the previous section show that the number of workers in the targeted industries/regions grew faster than in the non-targeted ones (panel (b) of figure 2) but there was no such difference in the number of establishments. It must follow that the average establishment size (measured by the number of workers per establishment) grew larger in the targeted than in the non-targeted industries/regions.

In Figure 4, we show how the establishment size distribution changed for both the targeted and the non-targeted industry-region pairs. Panels (a) and (b) are the log-log plots in 1967 and 1980. In a log-log plot, the horizontal axis is the log of the number of employees and the curve traces the log of the fraction of establishments with at least as many employees as the corresponding number on the horizontal axis. Panel (a) shows that, before the policy, the establishment size distributions of the targeted industries/regions and the non-targeted industries/regions were not too different. Going from 1967 to 1980, panel (b) shows that, after the policy, both log-log plots shifted to the right and became flatter, but much more so for the targeted industries/regions than for the non-targeted ones. A right shift of the log-log plot implies that there are more establishments at larger scales. ${ }^{12}$ The average size of an establishment in the targeted industry-region pairs increased from 30.4 in 1967 to 127.5 employees in 1980, while the average size in the non-targeted industry-region pairs increased from 26.8 to 63.2 over the same period. The flattening of the log-log plot implies that the right tail became thicker, with a disproportionate increase in the number of very large establishments.

There are at least two possible explanations for the differential shift in the size distribution between the targeted and the non-targeted industries/regions. One possibility is that establishments were smaller initially because of barriers to firm growth (e.g., credit constraints), and the industrial policy helped firms in the targeted industries overcome such barriers and grow larger. This view is consistent with the evidence provided by Buera and

\footnotetext{
${ }^{12}$ If all establishments grow proportionally in size, the log-log plot makes a parallel shift to the right.
} 


\section{Figure 4: Establishment Size Distribution}

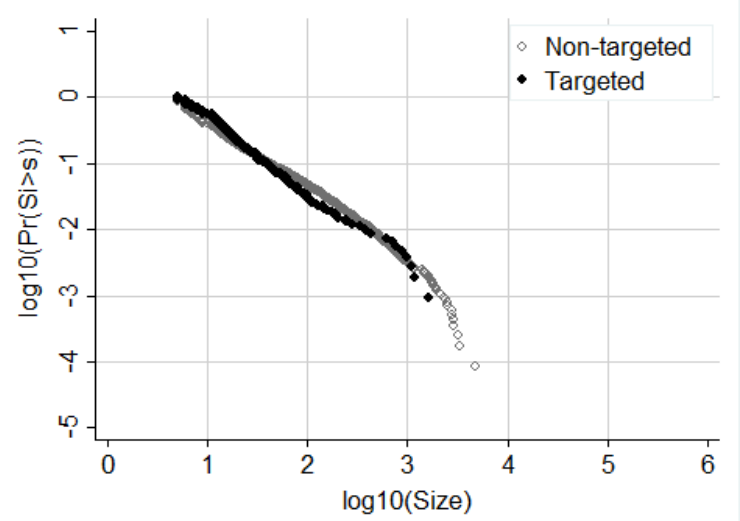

(a) Size in 1967

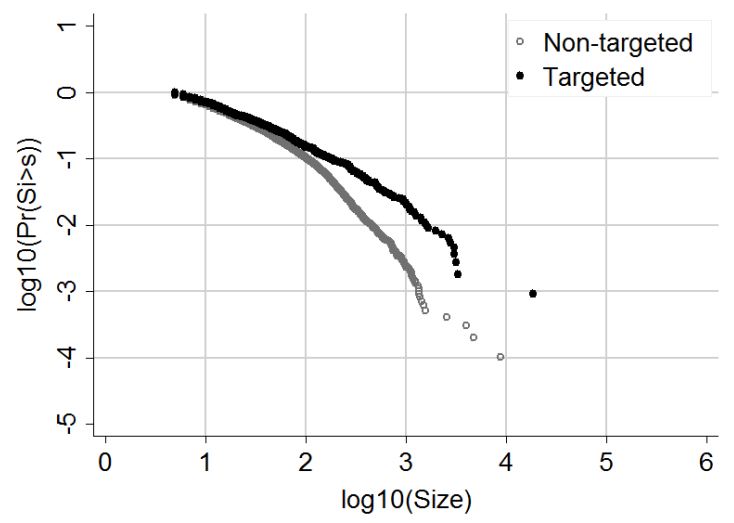

(a) Size in 1980 among age 0-7 plants

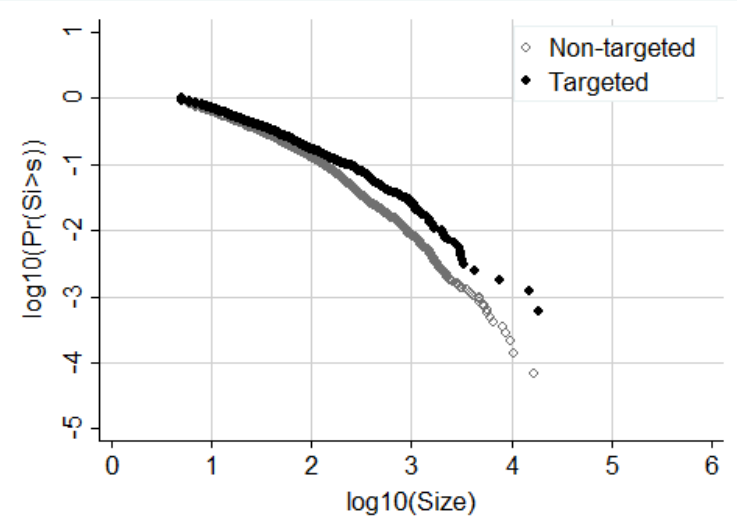

(b) Size in 1980

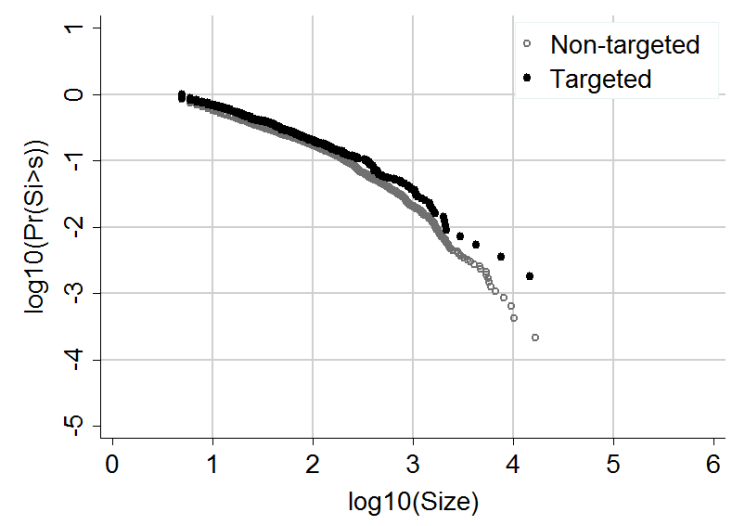

(b) Size in 1980 among age 8+ plants

Notes: Panels (a) to $(\mathrm{d})$ show the log of the fraction of establishments larger than or equal to size $s$ on the horizontal axis, where size is the number of employees. The data is truncated at 5 employees. The black dots are for the targeted industry-region pairs and the gray dots for the non-targeted ones. The three industries (chemicals, refined petroleum, and cement) that were excluded from the main analysis are included as targeted here. The results were similar when we excluded these three industries. 
Shin (2013). The other is that the shift in size distribution reflects the adoption of more productive modern production technologies in the targeted sector, partly subsidized by the industrial policy. This view is consistent with the analysis of Buera, Hopenhayn, Shin and Trachter (2021) and also with our finding that the establishment-level productivity increased significantly more in the targeted industries/regions. Because ours is repeated cross-sections and the establishment age is only available from 1980, the data does not permit a clean test of either hypothesis.

Nevertheless, a comparison of the young and old firms in 1980 again provides some insights. Panels (c) and (d) of Figure 4 are the log-log plots for the young (age 0-7) plants and the old (age 8 and older) plants in 1980. Panels (c) and (d) show that the size difference between the targeted and the non-targeted industries/regions is mostly accounted for by the young plants that entered during the policy period. Furthermore, we see that the size distributions of the young plants and the old plants in the targeted industries/regions - black dots in panels (c) and (d) - are nearly identical except for the few points at the right extreme. This very unusual fact, that young plants are as large as old plants, indicates that the cohort of plants that entered during the policy period in the targeted industries/regions was not a usual cohort, giving some weight to the technology adoption view. ${ }^{13}$

However, our results on concentration and misallocation raise an important caveat. The largest establishments in 1980 are not necessarily the most productive ones, and hence the selective support by the government and within business groups may be responsible for the emergence of the very large establishments.

\subsection{Change in Input-Output Networks}

The analysis so far shows that the targeted industries became a larger part of the economy. The natural next question is how their growth contributed to the overall economy - in particular, whether it also benefited the non-targeted industries.

\footnotetext{
${ }^{13}$ Although not shown in the paper, we did a similar exercise using the 1990 establishment size distribution. We find that (i) the size difference between the targeted and the non-targeted industries/regions among the plants that entered during the policy period persisted and got even larger through 1990; (ii) among the young plants (age 0-7) in 1990, even though the policy had ended in 1979, those in the targeted industries/regions are larger on average than those in the non-targeted ones, but the target vs. non-target difference is much smaller than among the young firms in 1980; and (iii) in the targeted industries/regions, the young firms in 1990 are significantly smaller than the old firms in 1990. Fact (i) shows the lasting impact of the policy for the continuing plants, consistent with the findings of Choi and Levchenko (2021). Fact (ii) suggests that, in addition, the policy may have had an effect even on the plants that entered after the policy period. It may capture the effect of the industrial complexes, which continued their operation well after the policy period. Facts (i) and (ii) are consistent to the persistent effect at the industry level in Lane (2021). Fact (iii), when compared to panels (c) and (d) of Figure 4, shows that the plants that entered during the policy period in the targeted industries/regions was a very unusual cohort.
} 
We provide formal evidence in Figure 5. Panels (a) and (b) show the input-output matrix of the Korean economy in 1970 and 1980, respectively. Industries are on the horizontal axis and the vertical axis, and the size of each dot shows the amount of input supplied by a given industry on the horizontal axis to one on the vertical axis. Black dots mean that both the input-supplying and the input-using industries are targeted. Dark gray dots represent that the input-supplying industry is targeted but the input-using industry is not. Comparing the two panels, one sees that the input-output matrix after the policy has more and larger black dots and dark gray dots. In other words, both the non-targeted and the targeted industries used more inputs produced by the targeted industries in 1980 than in 1970. The tables in panels (c) and (d) provide more precise numbers. In 1970, of all the intermediate inputs, about 15 percent (10.34 plus 4.76) were produced by the targeted industries. In 1980, this proportion nearly doubled to about 29 percent (15.14 plus 13.57). The intermediate input supplied by the targeted industries to the non-targeted industries accounted for 10 percent of all intermediate inputs in 1970 but 15 percent in 1980. While the increase was more pronounced for the intermediate input supplied by one targeted industry to another, it clearly shows that, through industrial linkages, the targeted industrial policy contributed to the growth of the non-targeted industries as well.

Another way of representing industries' importance in the input-output context is to compute the vector of sectoral multipliers $\mu$ using the Leontief inverse, $[\mathbf{I}-\boldsymbol{\Gamma}]^{-1}$, and the vector of expenditure shares, $\beta$, as in Fadinger, Ghiglino and Teteryatnikova (forthcoming):

$$
\mu=[\mathbf{I}-\mathbf{\Gamma}]^{-1} \beta
$$

The elements of the multipliers vector show the impact of a one-percent increase in the productivity of a given industry on the overall value-added of the economy. These multipliers are related to the notion of how upstream these industries are in the input-output structure.

Panel (e) plots an industry's multiplier in 1970 (horizontal axis) and 1980 (vertical axis), and the straight line is the 45-degree line. The 10 targeted industries are black dots and 44 non-targeted ones are gray dots. ${ }^{14}$ It shows that the multipliers of nearly all targeted industries increased between 1970 and 1980, while those of the non-targeted industries do not show a clear pattern. The table in panel (f) quantifies this finding by computing the averages across the targeted and the non-targeted industries in 1970 and 1980. One surprise is that, although the policy targeted heavy and chemical industries, the targeted industries were less upstream than the non-targeted industries in the 1970 input-output structure. Consistent with panel (e), the multipliers of non-targeted industries did not change much between 1970

\footnotetext{
${ }^{14}$ The number of industries are different here because the Bank of Korea used its own industry classification to produce the input-output matrices for these years.
} 
Figure 5: Change in IO Structure

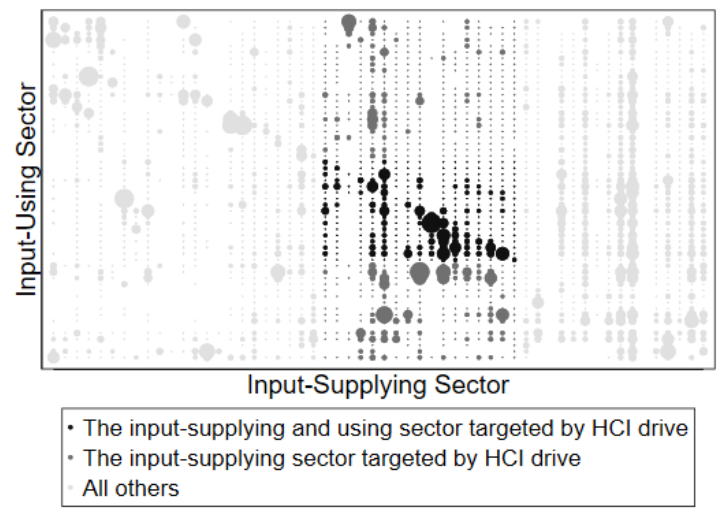

(a) IO Matrix in 1970 (c) Two-sector IO Matrix in 1970

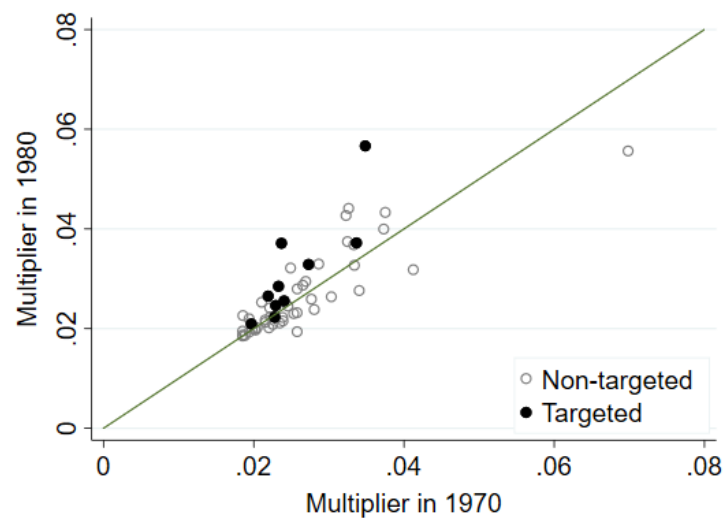

(e) Sectoral IO Multipliers

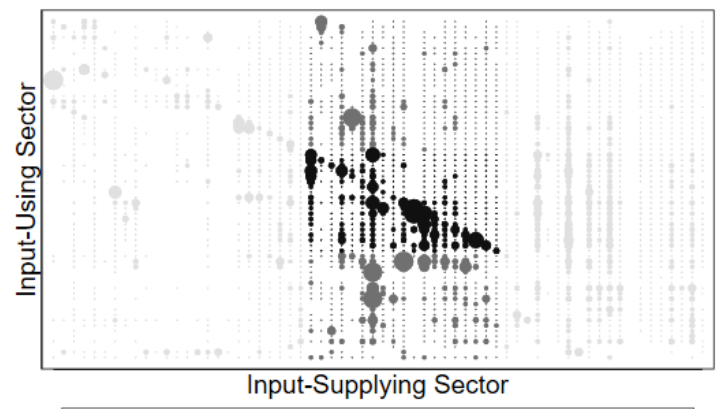

- The input-supplying and using sector targeted by $\mathrm{HCl}$ drive
- The input-supplying sector targeted by $\mathrm{HCl}$ drive
All others

(b) IO Matrix in 1980

\begin{tabular}{cc|cc} 
& & \multicolumn{2}{|c}{ supplying } \\
& & Non-target & Target \\
\hline \multirow{2}{*}{ using } & Non-target & $64.44 \%$ & $15.14 \%$ \\
& Target & $6.86 \%$ & $13.57 \%$
\end{tabular}

(d) Two-sector IO Matrix in 1980

\begin{tabular}{c|cc} 
& Non-target & Target \\
\hline 1970 & 0.0264 & 0.0254 \\
1980 & 0.0266 & 0.0312
\end{tabular}

Notes: Panel (a) and (b) show the input-output matrix in 1970 and 1980, respectively. Tables in panel (c) and (d) summarize Panel (a) and (b) into a two-sector input-output matrix. Panel (e) plots an industry's multiplier in 1970 (horizontal axis) and 1980 (vertical axis). Panel (f) reports the averages of the multipliers in targeted and non-targeted industries. 
and 1980, but those of the targeted industries increased on average. The increase of 0.0058 is around a 0.7 standard deviation of multipliers in 1970, and the increase is statistically significant at the 5 percent level. In addition, even after the policy was reversed in the early 1980s, the multipliers of both the targeted and the non-targeted industries remained stable between 1980 and 1990, underlining the persistence of the policy impact.

Another relevant fact comes from the trade data. The Korean growth miracle has been widely characterized as export-oriented (Kim and Leipziger, 1997). Using the United Nations Comtrade data, we find that the export of the targeted industries grew by 39 percent per year on average (in dollar terms) during the policy period of 1973-1979. Over the same period, even the non-targeted industry export grew significantly, by 25 percent per year on average. One possibility is that the targeted industries aided the export growth of the non-targeted industries by providing cheaper intermediate inputs of production. The government's annual export goal of 10 billion dollars was achieved in $1977 .{ }^{15}$

\section{Concluding Remarks}

Korea is often hailed as an example of successful government-led economic growth, but such statements have rarely been backed up by quantitative analysis. We provide the first plant-level view of the heavy industry drive of 1973. During the policy period, the targeted industry-region pairs grew significantly faster in terms of output, input use, and labor productivity than the non-targeted ones, suggesting the importance of place-based policies as well as industry-specific policies.

The policy had no significant impact on the TFP at the industry-region level because whatever positive effect it had on plant-level TFP was completely undone by worsened misallocation within the targeted industry-region pairs. The significant increase in the measures of misallocation and concentration within the targeted industries and regions, especially among the plants that entered during the policy period, shows that the additional resources flowing into the targeted industries and regions were not always allocated according to plant-level productivity.

In addition, we found that during the policy period the plant size distribution of the targeted industries and regions shifted significantly to the right with thicker tails, mostly due to the entry of large plants, and that the targeted industries became more important in the input-output structure of the economy. Future research will look for an explanation of

\footnotetext{
${ }^{15}$ The import data confirms that the policy was not import substituting. The import of the targeted industry products grew by 31 percent per year on average during the policy period, while the import of non-targeted industry products grew by 25 percent per year on average.
} 
the size distribution change and evaluate the economic impact of the evolved input-output structure, especially how the promotion of the targeted industries may have benefited even the non-targeted ones by supplying intermediate input more cheaply.

Some restrictions in our microdata precluded us from providing more important insights. Because we only have repeated cross-sectional data and the plant age variable is only available after the policy period, we cannot discuss the impact of the policy on plant-level dynamics. Furthermore, because we cannot link plants to firms or business groups, we cannot provide direct evidence on the alleged importance of chaebols or large business groups that dominated the Korean economy during the high-growth period. The rise in the concentration measures does suggest that large plants belonging to large business groups may have been the primary beneficiary of policies favoring specific industries and regions. As more data becomes available, we expect that hard numbers will further resolve the debate on the efficacy of industrial policy. 


\section{References}

Aghion, Philippe, Jing Cai, Mathias Dewatripont, Luosha Du, Ann Harrison, and Patrick Legros, "Industrial policy and competition," American Economic Journal: Macroeconomics, 2015, 7 (4), 1-32.

Ahn, Choong Yong and Joo-Hoon Kim, "The outward-looking trade policy and the industrial development of South Korea," in Dong-Se Cha and Kwang Suk Kim, eds., The Korean Economy 1945-1995: Performance and Vision for the 21st Century, Korea Development Institute, 1995, pp. 312-369.

Bau, Natalie and Adrien Matray, "Misallocation and capital market integration: Evidence from India," NBER Working Paper No. 27955, 2020.

Buera, Francisco J and Yongseok Shin, "Financial frictions and the persistence of history: A quantitative exploration," Journal of Political Economy, 2013, 121 (2), 221-272.

_, Hugo Hopenhayn, Yongseok Shin, and Nicholas Trachter, "Big Push in Distorted Economies," NBER Working Paper No. 28561, 2021.

Choi, Jaedo and Andrei A. Levchenko, "The Long-Term Effects of Industrial Policy," mimeo, 2021.

Criscuolo, Chiara, Ralf Martin, Henry G Overman, and John Van Reenen, "Some causal effects of an industrial policy," American Economic Review, 2019, 109 (1), 48-85.

Fadinger, Harald, Christian Ghiglino, and Mariya Teteryatnikova, "Income Differences, Productivity and Input-Output Networks," American Economic Journal: Macroeconomics, forthcoming.

Foster, Lucia, John Haltiwanger, and Chad Syverson, "Reallocation, firm turnover, and efficiency: Selection on productivity or profitability?," American Economic Review, 2008, 98 (1), 394-425.

Giorcelli, Michela, "The long-term effects of management and technology transfers," American Economic Review, 2019, 109 (1), 121-52.

Gopinath, Gita, Şebnem Kalemli-Özcan, Loukas Karabarbounis, and Carolina VillegasSanchez, "Capital allocation and productivity in South Europe," The Quarterly Journal of Economics, 2017, 132 (4), 1915-1967. 
Hanlon, W Walker, "The Persistent Effect of Temporary Input Cost Advantages in Shipbuilding, 1850 to 1911," Journal of the European Economic Association, 2020, 18 (6), 3173-3209.

Harrison, Ann and Andrés Rodríguez-Clare, "Trade, foreign investment, and industrial policy for developing countries," Handbook of Development Economics, 2010, 5, 4039-4214.

Hsieh, Chang-Tai and Peter J. Klenow, "Misallocation and Manufacturing TFP in China and India," The Quarterly Journal of Economics, 2009, 124 (4), 1403-1448.

Juhász, Réka, "Temporary protection and technology adoption: Evidence from the napoleonic blockade," American Economic Review, 2018, 108 (11), 3339-76.

Kim, Kihwan and Danny M Leipziger, "Korea: A case of government-led development," Lessons from East Asia, 1997, pp. 155-212.

Kim, Minho, Jiyoon Oh, and Yongseok Shin, "Misallocation and manufacturing TFP in Korea, 1982-2007," Federal Reserve Bank of St. Louis Review, 2017.

Kwack, Taewon, "Depreciation and Capital Taxation (in Korean)," Korea Development Institute Research Report 85-05, 1985.

Lane, Nathan, "Manufacturing Revolutions: Industrial Policy and Industrialization in South Korea," mimeo, 2021.

Lane, Nathaniel, "The New Empirics of Industrial Policy," Journal of Industry, Competition and Trade, 2020, pp. 1-26.

Lee, Jong-Wha, "Government interventions and productivity growth," Journal of Economic Growth, 1996, 1 (3), 391-414.

Lee, Munseob, "Government Purchases and Firm Growth," mimeo, 2021.

Levinsohn, James and Amil Petrin, "Estimating production functions using inputs to control for unobservables," The Review of Economic Studies, 2003, 70 (2), 317-341.

Liu, Ernest, "Industrial policies in production networks," The Quarterly Journal of Economics, 2019, 134 (4), 1883-1948.

Manelici, Isabela and Smaranda Pantea, "Industrial policy at work: Evidence from Romania's income tax break for workers in IT," European Economic Review, 2021, 133, 103674. 
Noland, Marcus and Howard Pack, Industrial policy in an era of globalization: Lessons from Asia, Vol. 69, Peterson Institute, 2003.

Park, Y, "Structural changes and the drive to heavy and chemical industry," New Korean economic history: From the late Joseon period to the high growth period of the 20th century, 2005, pp. 403-428.

Rotemberg, Martin, "Equilibrium effects of firm subsidies," American Economic Review, 2019, 109 (10), 3475-3513.

SaKong, Il and Youngsun Koh, The Korean economy: Six decades of growth and development, Korea Development Institute, 2010.

Stern, Joseph J, Ji hong Kim, Dwight H Perkins, and Jung ho Yoo, Industrialization and the state: The Korean heavy and chemical industry drive, Harvard University Press, 1995.

Woo, Jung-en, Race to the swift: State and finance in Korean industrialization, Columbia University Press, 1991.

Wooldridge, Jeffrey M, "On estimating firm-level production functions using proxy variables to control for unobservables," Economics letters, 2009, 104 (3), 112-114. 


\section{APPENDIX (NOT FOR PUBLICATION)}

\section{A List of Treated Industries and Regions}

Table A.I: List of Treated Industries

\begin{tabular}{llc}
\hline \hline Industry Code & Industry Name & Treatment Status \\
\hline & & $\mathrm{N}$ \\
311 & Food & $\mathrm{N}$ \\
313 & Beverage & $\mathrm{N}$ \\
321 & Textiles & $\mathrm{N}$ \\
322 & Apparel & $\mathrm{N}$ \\
323 & Leather & $\mathrm{N}$ \\
324 & Footwear & $\mathrm{N}$ \\
331 & Wood & $\mathrm{N}$ \\
332 & Wood furniture & $\mathrm{N}$ \\
341 & Paper,paper products & $\mathrm{N}$ \\
342 & Publishing, printing & $\mathrm{Y}^{*}$ \\
351 & Chemicals & $\mathrm{N}$ \\
352 & Other Chemical products & $\mathrm{Y}$ \\
353 & Refined petroleum & $\mathrm{N}$ \\
355 & Rubber and plastics & $\mathrm{N}$ \\
36 & Other non-metallic mineral products, except cement & $\mathrm{Y}$ \\
3692 & Manufacture of cement, lime and plaster & $\mathrm{Y}$ \\
371 & Manufacture of basic iron and steel & $\mathrm{Y}$ \\
372 & Manufacture of basic precious and other non-ferrous metals & $\mathrm{Y}$ \\
381 & Manufacture of fabricated metal products, except machinery and equipment & $\mathrm{Y}$ \\
382 & Manufacture of machinery and equipment n.e.c. & $\mathrm{Y}$ \\
3825 & Manufacture of office, accounting and computing machinery & $\mathrm{Y}$ \\
3831 & Manufacture of electrical machinery and apparatus n.e.c.
\end{tabular}

Note: The table reports 13 treated and 15 untreated industries. * denotes industries that were targeted before 1972. 


\section{Table A.II: List of Treated Regions}

\begin{tabular}{llc}
\hline \hline Region Code & Region Name & Treatment Status \\
\hline & & \\
11 & Seoul & $\mathrm{N}$ \\
21 & Busan & $\mathrm{N}$ \\
31 & Gyeonggi-do, Incheon & $\mathrm{N}$ \\
32 & Gangwon-do & $\mathrm{N}$ \\
33 & Chungcheongbuk-do & $\mathrm{N}$ \\
34 & Chungcheongnam-do, Daejeon & $\mathrm{N}$ \\
35 & Jeollabuk-do & $\mathrm{N}$ \\
36 & Jeollanam-do, Gwangju & $\mathrm{Y}$ \\
37 & Gyeonngsangbuk-do, Daegu & $\mathrm{Y}$ \\
38 & Gyeonngsangnam-do, Ulsan & $\mathrm{Y}$ \\
39 & Jeju-do & $\mathrm{N}$ \\
& & \\
\hline \hline
\end{tabular}

Note: The national industrial complexes were built for heavy chemical industries in the treated region. Regional name with "-do" corresponds to province in Korea. 


\section{B Trends in Targeted vs Non-targeted Industries/Regions}

Figure B.1: Output, Input, and Productivity

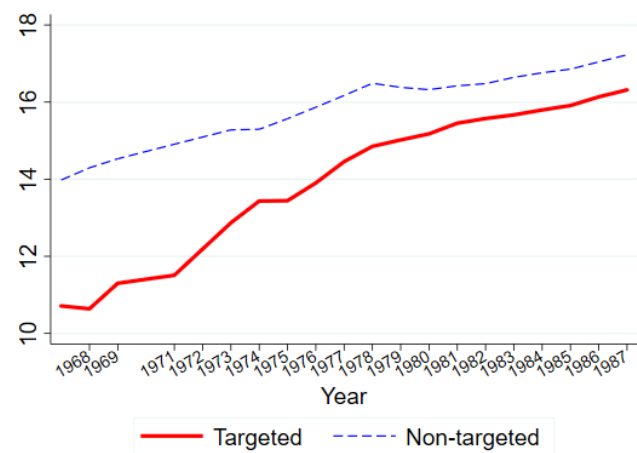

(a) Log of Total Real Value-added

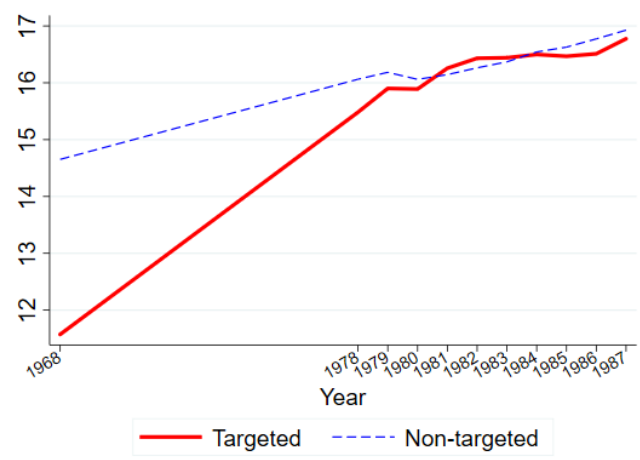

(c) Log of Total Real Capital Stock

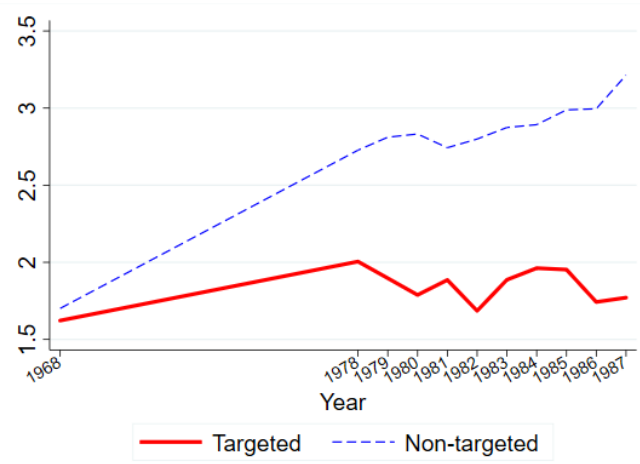

(e) Average Total Factor Productivity

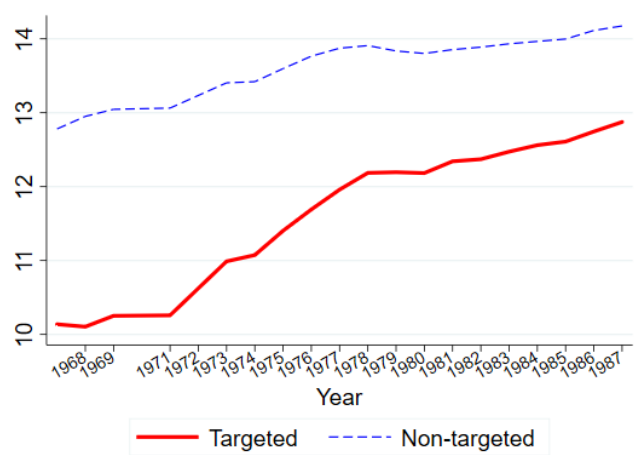

(b) Log of Total Number of Employees

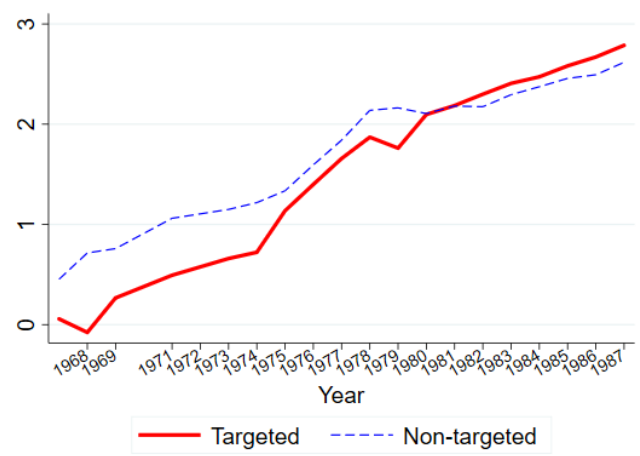

(d) Average Labor Productivity

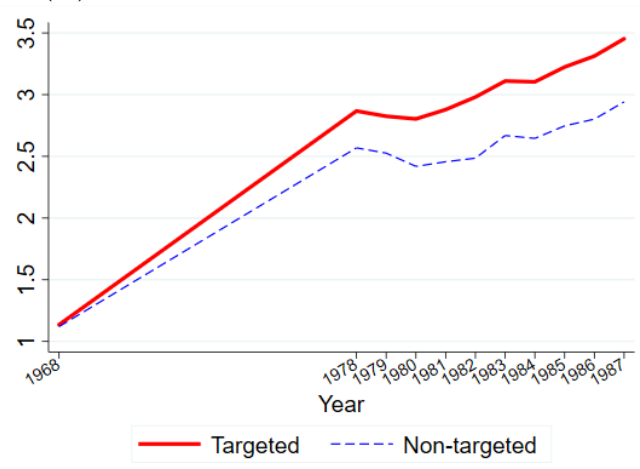

(f) Simple Average of Establishment-level TFP

Notes: Panels (a), (b), and (c) plot logs of sum of variables across targeted and non-targeted industry-region pairs. Panel (d) is an average labor productivity weighted by the number of employees. Panel (e) is an average total factor productivity weighted by real value added. Panel (f) is a simple average of establishment-level TFPs weighted by real value added across industries/regions. 
Figure B.2: Allocative Efficiency
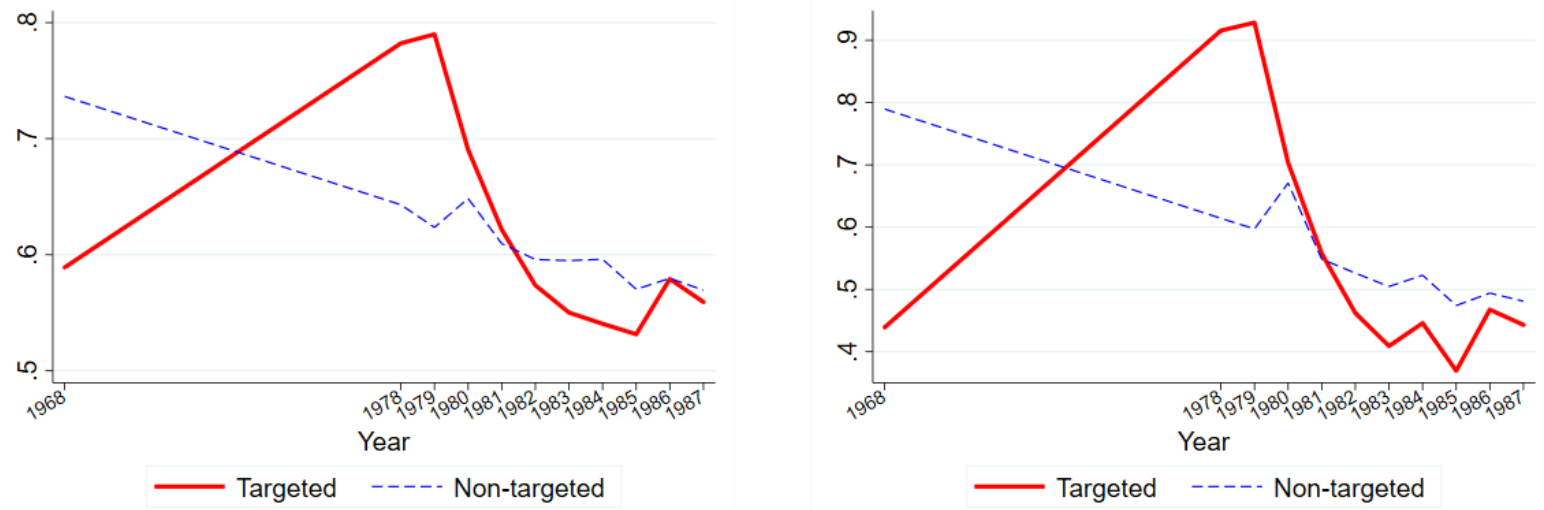

(a) Average Standard Deviation of TFPR

(b) Average Correlation b/w TFPR \& TFPQ

Notes: Panels (a) to (b) plot the weighted average across targeted and non-targeted industry-region pairs. Weights are real value added. 


\section{Results with only industry targets}

\section{Figure C.1: Output, Input, and Productivity}

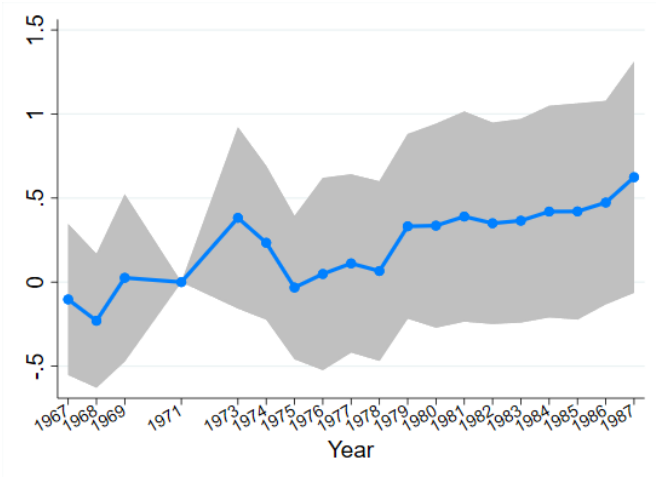

(a) Real Value-added

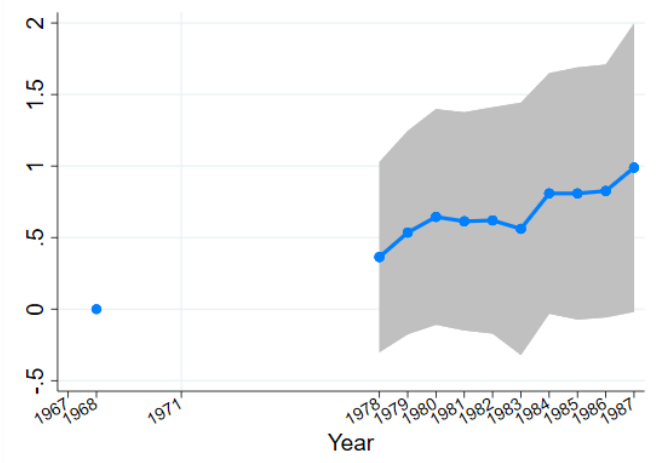

(c) Real Capital Stock

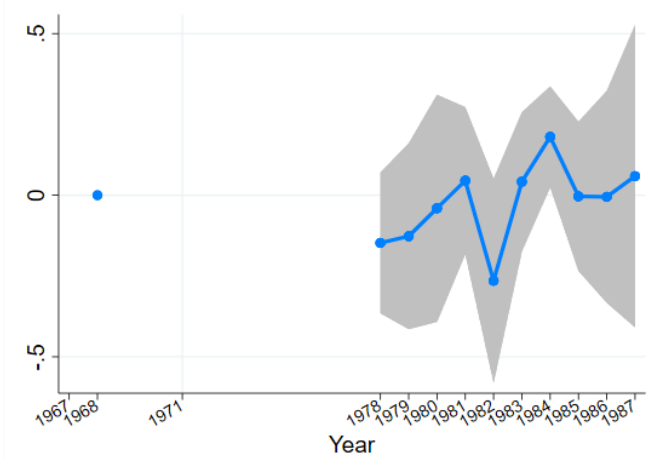

(e) Total Factor Productivity

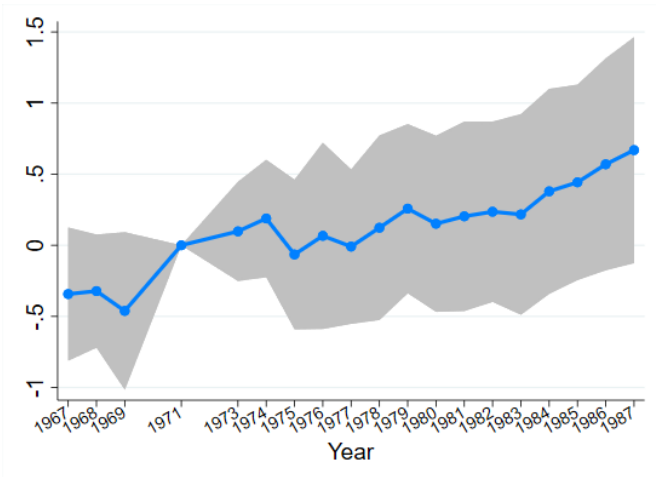

(b) Number of Employees

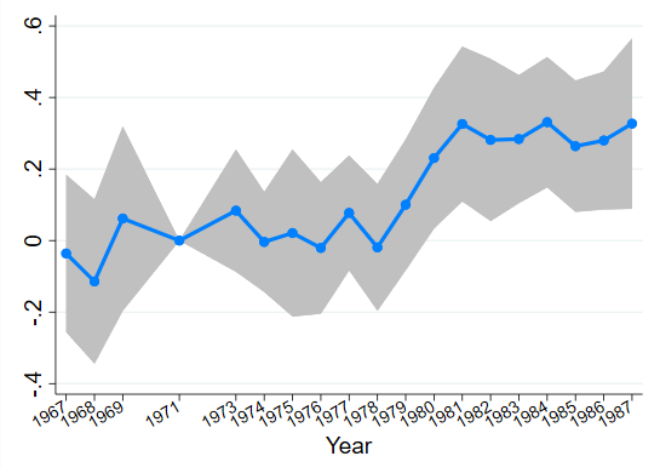

(d) Labor Productivity

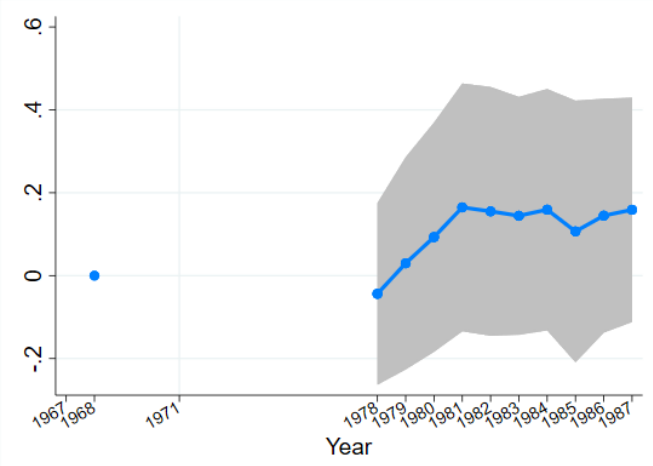

(f) Simple Average of Establishment-level TFPs

Notes: Panels (a) to (f) plot estimated coefficients along with a 95 percent confidence interval. The microdata does not exist in 1970 and 1972, and the year of 1971 is normalized to zero. We adjust standard errors with clustering over industry. Regression weights are dependent variable itself in panels (a), (b), and (c). We use the number of employees as a regression weight for panel (d) and real value added for panels (e) and (f). 
Figure C.2: Allocative Efficiency

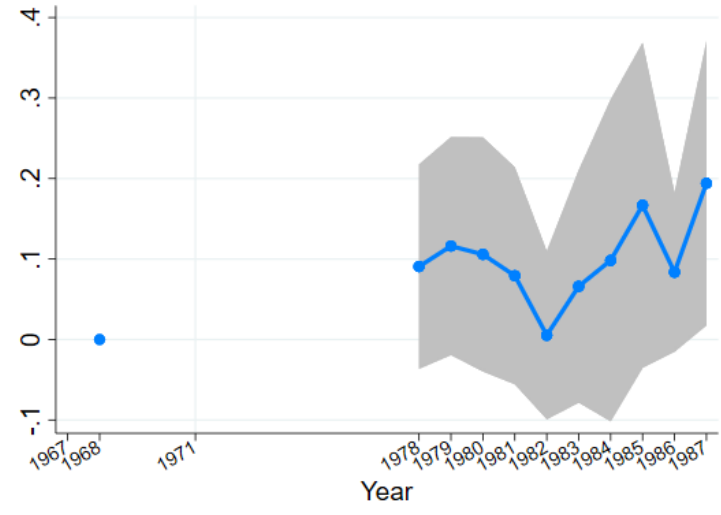

(a) Standard Deviation of TFPR

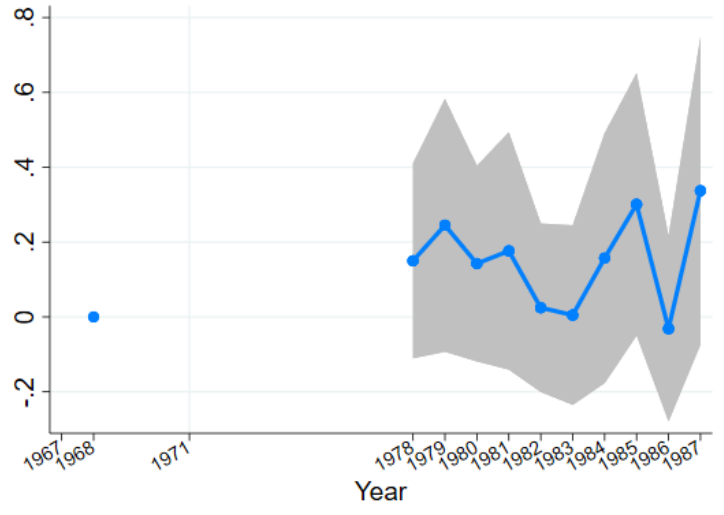

(b) Correlation b/w TFPR \& TFPQ

Notes: Panels (a) to (b) plot estimated coefficients along with a 95 percent confidence interval. We adjust standard errors with clustering over industry. Regression weights are real value added. 


\section{TFP Estimation}

We estimate total factor productivity (TFP) at the plant-level under the assumption of a Cobb-Douglas production function. We use the value-added specification of the production function as follows.

$$
\log V A_{i t}=\log A_{i t}+\epsilon_{s}^{K} \log K_{i t}+\epsilon_{s}^{L} \log L_{i t}+\epsilon_{i t}
$$

where $V A_{i t}$ is the real value-added and $A_{i t}$ is the TFP measure. We estimate the elasticities of the log of capital $\left(K_{i t}\right)$ and labor $\left(L_{i t}\right)$, which are the coefficients of the equation 6 . We apply the estimation method of Wooldridge (2009) to estimate the elasticity parameters for each 28 three-digit industries. Wooldridge (2009) applies a generalized method of moments (GMM) framework to Levinsohn and Petrin (2003), where they use the proxy variables in estimation to control for the simultaneity problem caused by the correlation between unobserved productivity and the production inputs. We used the lag value of labor input as instruments. Since the method requires the use of lagged input variables, we use the unbalanced panel data constructed from MMS between the years 1981 and 1990. Thus, we are implicitly applying the same constant estimated elasticities of inputs for each industry to other periods of analysis. The estimated coefficients are reported in the Appendix Table D.I. 


\section{Table D.I: Production Function Estimates}

\begin{tabular}{|c|c|c|c|c|c|}
\hline \multicolumn{2}{|c|}{$\begin{array}{l}\text { Industry Industry name } \\
\text { Code }\end{array}$} & \multirow{2}{*}{$\begin{array}{l}\begin{array}{l}\text { Coeff. of capital } \\
\text { (s.d.) }\end{array} \\
0.16(0.0066)\end{array}$} & \multirow{2}{*}{$\begin{array}{l}\begin{array}{l}\text { Coeff. of labor } \\
\text { (s.d.) }\end{array} \\
0.59(0.0093)\end{array}$} & \multirow{2}{*}{$\begin{array}{l}\text { No. of obs. } \\
24973\end{array}$} & \multirow{2}{*}{$\begin{array}{l}\text { No. of ests. } \\
7126\end{array}$} \\
\hline 311 & Food & & & & \\
\hline 313 & Beverage & $0.04(0.0089)$ & $0.67(0.0277)$ & 7551 & 1418 \\
\hline 321 & Textiles & $0.12(0.0036)$ & $0.71(0.0049)$ & 45682 & 18007 \\
\hline 322 & Apparel & $0.1(0.0034)$ & $0.76(0.0043)$ & 28555 & 16088 \\
\hline 323 & Leather & $0.1(0.0092)$ & $0.74(0.015)$ & 5612 & 3458 \\
\hline 324 & Footwear & $0.13(0.011)$ & $0.76(0.0149)$ & 3997 & 3244 \\
\hline 331 & Wood & $0.1(0.0072)$ & $0.7(0.013)$ & 12537 & 4345 \\
\hline 332 & Wood furniture & $0.09(0.0074)$ & $0.75(0.0187)$ & 7502 & 4130 \\
\hline 341 & Paper, paper products & $0.14(0.0099)$ & $0.49(0.0145)$ & 10279 & 4374 \\
\hline 342 & Publishing, printing & $0.09(0.0051)$ & $0.77(0.0101)$ & 14881 & 6652 \\
\hline 351 & Chemicals & $0.18(0.0148)$ & $0.43(0.0215)$ & 5446 & 2567 \\
\hline 352 & Other Chemical products & $0.14(0.0141)$ & $0.64(0.0141)$ & 6094 & 2262 \\
\hline 353 & Refined petroleum & $0.2(0.0369)$ & $0.19(0.0564)$ & 728 & 286 \\
\hline 355 & Rubber and plastics & $0.11(0.0058)$ & $0.74(0.0077)$ & 21815 & 11319 \\
\hline 36 & $\begin{array}{l}\text { Other non-metallic mineral } \\
\text { products, except cement }\end{array}$ & $0.16(0.0073)$ & $0.53(0.0095)$ & 16867 & 6826 \\
\hline 3692 & Cement, lime and plaster & $0.18(0.0648)$ & $0.22(0.0644)$ & 470 & 164 \\
\hline 371 & Basic iron and steel & $0.16(0.0125)$ & $0.52(0.0155)$ & 5179 & 2433 \\
\hline 372 & $\begin{array}{l}\text { Basic precious and other non- } \\
\text { ferrous metals }\end{array}$ & $0.1(0.0164)$ & $0.6(0.0264)$ & 3524 & 1876 \\
\hline 381 & Fabricated metal products & $0.15(0.0054)$ & $0.62(0.0085)$ & 25756 & 13625 \\
\hline 382 & Machinery and equipment & $0.14(0.0053)$ & $0.66(0.0089)$ & 25638 & 14762 \\
\hline 3825 & $\begin{array}{l}\text { Office, accounting and com- } \\
\text { puting machinery }\end{array}$ & $0.09(0.0323)$ & $0.64(0.0351)$ & 975 & 782 \\
\hline 3831 & $\begin{array}{l}\text { Electrical machinery and ap- } \\
\text { paratus n.e.c. }\end{array}$ & $0.12(0.0079)$ & $0.59(0.0111)$ & 11587 & 6819 \\
\hline 3832 & $\begin{array}{l}\text { Radio, television and commu- } \\
\text { nication equipment and appa- } \\
\text { ratus }\end{array}$ & $0.15(0.0073)$ & $0.62(0.0081)$ & 13028 & 7711 \\
\hline 384 & Other transport equipment & $0.15(0.0245)$ & $0.57(0.0428)$ & 1385 & 786 \\
\hline 3841 & $\begin{array}{l}\text { Building of ships, boats, and } \\
\text { floating structures }\end{array}$ & $0.05(0.0151)$ & $0.93(0.0185)$ & 2839 & 1173 \\
\hline 3843 & Motor vehicles and parts & $0.16(0.0112)$ & $0.56(0.0165)$ & 7327 & 4328 \\
\hline 385 & $\begin{array}{l}\text { Medical, precision and opti- } \\
\text { cal instruments, watches and } \\
\text { clocks }\end{array}$ & $0.15(0.0111)$ & $0.57(0.0164)$ & 4753 & 2624 \\
\hline 390 & Manufacturing n.e.c. & $0.09(0.0057)$ & $0.69(0.0074)$ & 14680 & 8238 \\
\hline
\end{tabular}

Note: The table reports the coefficients (and their clustered standard errors) of production function estimation. It also reports both the number of observations and the number of establishments in the unbalanced panel. 


\section{E Trade}

The trade data comes from the UN Comtrade Database. We first converted the values of exports and imports reported in SITC Rev. 2 into ISIC Rev. 2 using a concordance table, and second, matched ISIC Rev. 2 to KSIC Rev. 5. Figure E.1 shows that both exports and imports grew very rapid between the years 1968 and 1979. The non-targeted industry export values were much larger in the early period and they were caught up by targeted industry export values in the later period.

\section{Figure E.1: Exports and Imports}

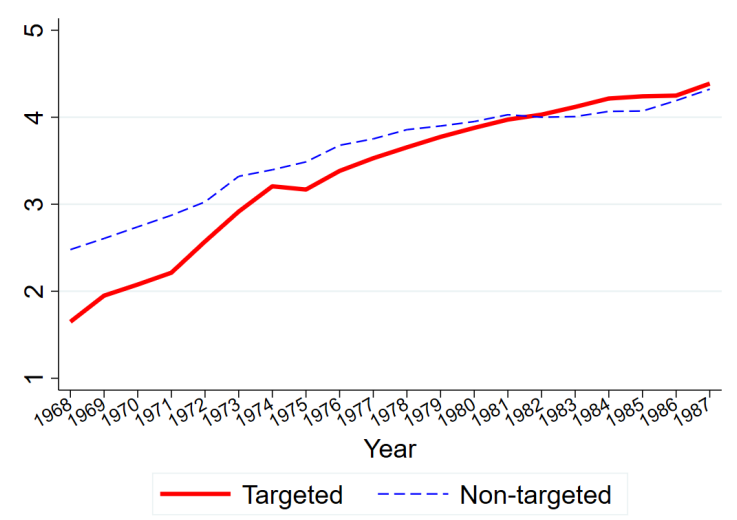

(a) Exports

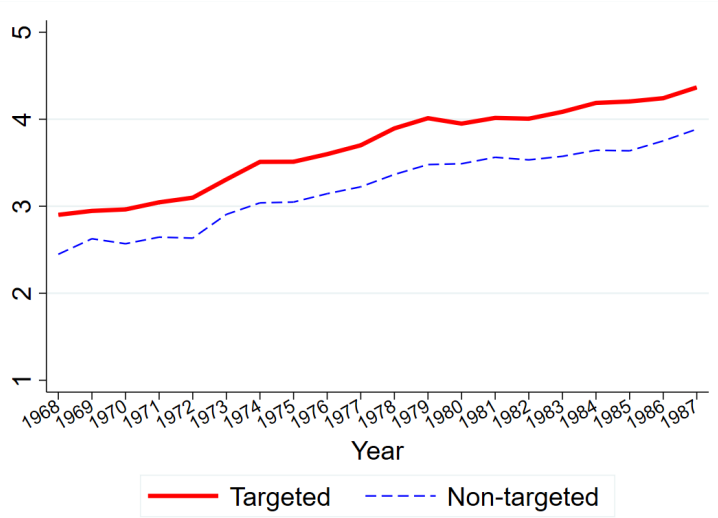

(b) Imports

Notes: Panels (a) and (b) plot log10 value of total exports and imports in million of dollars by targeted and non-targeted industry. 